\title{
МИГРАЦИОННАЯ ПОЛИТИКА МЕЖДУ ПРАВАМИ ЧЕЛОВЕКА И БЕЗОПАСНОСТЬЮ
}

13 февраля 2019 г. в Институте Европы РАН прошла международная конференция «Миграционная политика между правами человека и безопасностью». Её организаторами выступили ИЕ РАН совместно с Институтом лингвоцивилизационных и миграционных процессов (ИЛМП) при Фонде «Русский мир» в сотрудничестве с Фондом Фридриха Науманна. В число участников конференции, наряду с сотрудниками ИЕ РАН, вошли представители Совета экспертов ИЛМП, МИД России, руководители Московского бюро Фонда Фридриха Науманна и филиала Фонда Ханнса Зайделя в России, эксперты из Италии, Норвегии, Ирландии, Германии, ЮАР.

С приветствиями к собравшимся выступили Ал.А. Громыко, член-корр. РАН, директор ИЕ РАН, председатель Совета экспертов ИЛМП, Юлиус фон Фрайтаг-Лорингховен, руководитель Московского бюро Фонда Фридриха Науманна, В.Ю. Зорин, первый заместитель Председателя Совета Ассамблеи народов России, член Совета экспертов ИЛМП, руководитель Центра по научному взаимодействию с общественными организациями, СМИ и органами государственной власти Института этнологии и антропологии РАН.

Открывая конференцию, Ал.А. Громыко отметил, что проводимое мероприятие носит не только сугубо академический характер. «Реализация данного проекта направлена не только на научные открытия и достижения, а на получение практических результатов, чтобы наука превратила жизнь людей, особенно тех, кто в этом очень нуждается, в более благоприятную среду для обитания, для достижения своих целей в жизни, - подчеркнул Ал.А. Громыко.

Юлиус фон Фрайтаг-Лорингховен заявил, что тема конференции отсылает собравшихся к давнему спору о выборе между безопасностью и свободой. «Тем не менее, - подчеркнул он, - мы должны выбрать свободу, так как только свобода обеспечивает действительную безопасность». В Германии ранее был распространён подход, отражённый в термине «гастарбайтер», подразумевающий, что приезжий рабочий - гость, который должен вернуться обратно, и не интегрируется в принимающее сообщество. С тех пор подход к проблеме интеграции мигрантов существенно изменился. В этой связи г-н фон Фрайтаг-Лорингховен привёл цитату из книги Аладина Эль Мафаалани, мигранта второго поколения «Парадокс интеграции», в которой автор, в частности, пишет, что «индикатором успешной интеграции служит растущее количество вопросов и проблем, обсуждаемых в обществе. Парадокс успешной интеграции состоит в том, что она ведёт к большему количеству конфликтов и активной общественной дискуссии».

В.Ю. Зорин отметил в своём выступлении, что тема миграции вылилась в самостоятельное направление научных исследований и российской политики только в начале 2000 -х гг. На высоком уровне до 2003-2004 гг. слово «миграция» вообще не произносилось, поскольку

(С Грачёва Марина Леонидовна - старший научный сотрудник ИЕ РАН. Адрес: 125009, Россия, Москва, ул. Моховая, д. 11, стр. 3. E-mail: m.konnova@mail.ru.

DOI: http://dx.doi.org/10.15211/vestnikieran12019165170 
$80 \%$ всей нашей миграции - это бывший Советский Союз, республики Центральной Азии. Сейчас, на основе европейского и международного опыта, активно разрабатывается, совершенствуется российское миграционное законодательство, в том числе закон об адаптации и интеграции мигрантов. За всю тысячелетнюю историю, по словам Зорина, мегатрендом политики государства было сохранение народов, языков и культур. «И поэтому, - заметил В.Ю. Зорин, - мы не ставим вопрос ассимиляции. Но разговор идёт об интеграции. Народ двигался, двигается и будет дальше двигаться. И нам придётся заниматься миграцией ещё не один год».

Программа конференции состояла из двух сессий и последующих за ними дискуссий. Ведущим первой сессии был Ал.А. Громыко, второй - В.Б. Белов, заместитель директора по научной работе ИЕ РАН.

Тема первой сессии «Миграция и безопасность» была раскрыта в выступлениях Сонии Лукарелли, профессора Университета Болоньи, Ю.А. Колесникова, независимого эксперта, консультанта МИД Росси, члена Совета экспертов ИЛМП, Томаса Диеза, профессора Тюбингенского университета, О.Ю. Потемкиной, заведующей Отделом исследований европейской интеграции ИЕ РАН и П.В. Осколкова, научного сотрудника Отдела исследований европейской интеграции ИЕ РАН.

Сониа Лукарелли в своём докладе «ЕС и миграция: между защитой прав и страхом» отметила, что Европейский союз всегда позиционировал себя как открытое общество, а также как общество, не готовое идти на компромиссы во всём, что касается уважения прав человека. Эти принципы, по словам профессора Лукарелли, подверглись проверке в последние годы в связи с возрастанием миграционного давления. Речь идёт не только о правах мигрантов на поиск лучшей жизни, но и о правах принимающих обществ, а также о возможности системы обеспечить безопасность и поддержание «управляемой гомогенности».

Начиная с 2015 г., наблюдается тренд на растущую секьюритизацию миграции, особенно в странах на внешних границах ЕС - Венгрии, Италии, Греции. Сложившаяся ситуация привела к нарушению режима Шенгенского соглашения, усилению контроля на внешних границах. В общественном восприятии укрепилась связь между иммиграцией и терроризмом и восприятие ислама как угрозы.

Среди европейских стран Италия сегодня находится на передней линии решения вопросов, связанных с миграционными потоками. Миграционная тема «внесла свой вклад» в противоречия, которые возникли в последнее время в Италии и Франции. С. Лукарелли упомянула в своём выступлении о таких важнейших этапах по регулированию этих проблем, как соглашение ЕС с Турцией и ряд проектов, запущенных Евросоюзом для того, чтобы решать эту проблему у берегов Ливии и на самой ливийской территории.

Ю.А. Колесников посвятил своё выступление усилиям международного сообщества по решению современных миграционных процессов. Он отметил, что для России тема иммиграции является относительно новой. Страна постепенно втягивается в те иммиграционные процессы, которые уже имели место в мире, на ходу создавая собственное миграционное законодательство. По словам эксперта, проблемы международной иммиграции, которые касаются РФ, отличаются от той ситуации, которая сложилась в 2014-2015 г. в Европе. «Наша миграция это миграция, прежде всего, из стран - республик бывшего Советского Союза. Заинтересованность в трудовых мигрантах очень важна для народно-хозяйственного комплекса России, заявил Колесников. Что же касается событий в Европе в 2014-2015 гг., Ю.А. Колесников не согласился с мнением европейцев, которые сформулировали их как миграционный кризис.

Конкретными практическим шагами, которые были предприняты международным сообществом, стала попытка разработать документ или серию документов, которые бы включали 
в себя цели, правила и принципы миграционной политики на международной арене. И основным «мотором» всех этих процессов, по словам Колесникова, были европейские страны и многие страны исхода мигрантов. Они приняли самое активное участие в подготовке документов по миграционным вопросам и развитию.

Россия поддержала европейскую нормотворческую деятельность, высказавшись за то, что это важные шаги, обеспечивающие определение подхода к решению сложных миграционных проблем с учётом современных тенденций и того опыта по регулированию миграционных и трудовых потоков, которые имеются у отдельных стран, а также с учётом национального интереса каждой из страны, которая привлекает рабочую силу в национальную экономику.

Томас Диез в докладе «Секьютеризация миграции» уделил особое внимание концепции секьюритизации. По его словам, это дискурсивный процесс, подразумевающий конструирование образа - не только угрозы, но и объекта этой угрозы; в том числе, секьюритизация - один из способов конструирования национальной идентичности. Когда эта концепция была введена в оборот в 1990-е гг., речь шла именно о миграции. Секьюритизация миграции, по мнению профессора, имеет два негативных эффекта: ограничение политических возможностей и стремление исключить мигрантов из принимающего общества. Можно говорить о секьюритизациях во множественном числе, потому как образ мигрантов складывается по-разному в разных секторах: в экономике - как угроза рынку труда, в социальной сфере - как угроза культуре и идентичности, в политике - как угроза импорта конфликтов, в военной сфере - как угроза терроризма. Подводя итог своему выступлению, г-н Диез отметил, что в любой политике присутствует элемент секьюритизации, вопрос в степени и пропорции, и сейчас уровень секьюритизации в общественных дискуссиях очень высок.

О.Ю. Потемкина, говоря о проблеме иностранных боевиков, подчеркнула её актуальность и то, что она является общей для России и Европейская союза. «Это как раз та сфера, где стороны проявляют одинаковую обеспокоенность возвращением из зон боевых действий боевиков, которые готовят террористические акты и, самое главное, создают спящие ячейки, занимаются вербовкой молодежи и пропагандой. Даже статистические данные говорят о примерно одинаковом масштабе проблемы, - заметила О.Ю. Потемкина.

О.Ю. Потемкина рассмотрела проблему иностранных боевиков-террористов в двух аспектах: безопасности и прав человека. Говоря о первом, она подчеркнула, что не стоит недооценивать эту угрозу, представляющую на сегодняшний день глобальную мировую проблему. Что же касается второго аспекта, то, по словам Потемкиной, как и мировое сообщество, Россия заинтересована в том, чтобы эти люди вернулись к нормальной мирной жизни и не участвовали в террористических действиях. «Но Россия предпочитает сбалансированную позицию в этом вопросе между социальной интеграцией и неотвратимостью наказания за террористические действия, - подчеркнула докладчица. «Задача - как мировому сообществу, так и России и Европейскому союзу - обратить внимание на эту продолжающуюся угрозу и свои усилия устремить на её предотвращение, - резюмировала О.Ю. Потемкина.

П.В. Осколков поднял тему антииммиграционной риторики европейских правых популистов. По его словам, европейские правые популисты за последние годы пережили всплеск определённой популярности и электоральных результатов. «Но, - подчеркнул докладчик, необходимо учитывать, что популизм сам по себе не является самостоятельной идеологией. Это лишь стратегия привлечения голосов, стратегия электоральной борьбы». Выступающий обратился к тому, что сказал профессор Диез о фрейминге, как образ иммигрантов конструируют и фреймируют. Осколков согласился с профессором Лукарелли, что именно правопопулистские партии конструируют образ угрозы, иммиграционного вторжения. Как пример по- 
добного фрейминга докладчик привёл книгу одного из лидеров партии фламандской правопопулистской партии «Фламандский интерес» Филиппа де Винтера «Иммиграционное вторжение. Новая колонизация». Правопопулистские партии также в своих предвыборных кампаниях активно используют визуализацию образа мусульманского иммигранта.

Подводя итог своему выступлению, П.В. Осколков заметил, что «вопрос иммиграции в риторике правопопулистских партий будет присутствовать, пока есть мигранты, пока это актуальный вопрос, который может вызвать определённый эмоциональный отклик у избирателей».

На второй сессии было рассмотрено влияние миграции на общество принимающих государств. Этой теме посвятили свои выступления О.С. Чудиновских, заведующая лабораторией экономики народонаселения и демографии экономического факультета МГУ им. М.В. Ломоносова, член Совета экспертов ИЛМП, М.И. Тисленко, специалист службы проректора РУДН по дополнительному образованию, Л.С. Биссон, старший научный сотрудник Отдела исследований европейской интеграции ИЕ РАН, Т.А. Васильева, заведующая Сектором сравнительного права и прав человека Института государства и права РАН, член Совета экспертов ИЛМП, а также Н.С. Ревенко, ведущий научный сотрудник Института исследований международных экономических отношений Финансового университета при Правительстве РФ.

О.С. Чудиновских тему своего доклада «Реальное и идеальное в новой концепции государственной миграционной политики России» раскрыла с помощью презентации. По словам выступающей, миграционная политика каждой страны состоит из определённых структурных элементов: это институты, которые ей управляют, законодательная база, инструменты, виды на жительство, визы, и иногда страны ещё принимают определённого рода стратегическую доктрину. В случае России роль такой доктрины выполняет Концепция государственной миграционной политики. Первая такая концепция была принята в 2012 г. В октябре 2018 г. утверждена новая Концепция государственной миграционной политики на период 2019-2024 гг. Если в прежнем документе, как отметила О.С. Чудиновских, цели были сформулированы достаточно лаконично и прагматично, то в новом появилась идея сохранения культурного кода, который мало кто понимает.

Прокомментировав, насколько была реализована предыдущая концепция, докладчица ознакомила собравшихся с основными положениями новой концепции, обратив особое внимание на спорные моменты и её внутренние противоречия. По мнению эксперта, в новой концепции много положений, не имеющих объективной основы и ничем не подкреплённых. Есть сдвиг в сторону желаемых, идеальных целей, которых невозможно достичь даже в отдалённой перспективе, а не только за пять лет. По мнению Чудиновских, многих ошибок в концепции можно было бы избежать, если бы она была предметом экспертного обсуждения. «Повышению реалистичности принимаемых нововведений может способствовать экспертное обсуждение с привлечением работников науки и правозащитных организаций. Баланс и возможность смещения от идеального к реальному будут зависеть от общеполитической ситуации в России и от места сюжета иммиграции в повестке внутренней и международной политики, - peзюмировала Чудиновских.

М.И. Тисленко в своём выступлении «Интеграция или анклавизация - выбор современного мигранта» обратила внимание на то, что заявленный ею выбор в названии доклада не дихотомичен по своей сути. Раскрывая тему, докладчица опиралась на опыт не только России, но и зарубежных коллег. Так как тема анклавов, по её мнению, очень политизирована и рождает пространство для популизма, то необходимо прояснить позицию по ней и понять для себя, что существует на самом деле много анклавов. Приведя в качестве примера разные типы анклавов и причины их возникновения, М.И. Тисленко отметила, что они не являются каким-то 
злом или «осиным гнездом», но всё-таки представляют определённую угрозу для принимающего сообщества. В качестве примера она привела стихийно возникший в 1998 г. лагерь в Кале, который был ликвидирован в 2016 г., поскольку начал представлять определённую уг-розу для безопасности Франции. Этот вопрос был вынесен на общенациональный уровень.

В своём докладе «Обеспечение прав мигрантов в ЕС и России: путь к расширению прав и возможностей» Л.С. Биссон выделила основные различия подходов к интеграции мигрантов, существующие в Европейском союзе и России.

Докладчик отметила, что политика Евросоюза в сфере интеграции граждан третьих стран зиждется на двух опорах. Первая предполагает, что наделение иммигрантов определёнными правами и статусом максимально способствует их интеграции в принимающее сообщество. Права прямым образом связаны с готовностью иммигрантов интегрироваться. Однако на наднациональном уровне действует обратная логика. Вторая опора содержит совокупность юридически не обязывающих мер, мероприятий и принципов, которые могут быть обозначены как рамки интеграции граждан третьих стран в Европейском союзе. Рамки представляют собой механизм мягкого права и пример многоуровневого управления. Главным инструментом служат общие базовые принципы интеграции иммигрантов.

В Российской Федерации подавляющая часть иностранных граждан относится к категории временно пребывающих. Именно с этим связано то, что до настоящего времени в стране на государственном уровне не были приняты специальные программы адаптации и интеграции иммигрантов. В российском подходе к интеграции иммигрантов превалирует культурное, а не социально-экономическое измерение. В новой редакции Концепции миграционной политики России не упомянуты права, которыми обладают граждане третьих стран на территории РФ, речь ведётся лишь о правилах, услугах, процедурах, в то время как при выстраивании миграционной политики Европейский союз во главу угла ставит концепцию прав человека, закрепляя базовые права граждан третьих стран на семейную жизнь, достойные условия труда и т.П.

Т.А. Васильева в своём докладе «Правовые последствия миграционного кризиса: европейское и национальные измерения» осветила ряд правовых аспектов, которые проявились в ходе миграционного кризиса. По мнению юриста, кризис поставил под угрозу определённые европейские ценности, такие, к примеру, как принцип солидарности, являющийся одним из ключевых принципов, на которых базируется Европейский союз.

Что касается правового положения лиц, которые приезжали в Европейский союз, то в некоторых странах - членах ЕС под угрозу был поставлен принцип уважения достоинства личности. Кризис также показал, что Дублинское соглашение разными государствами выполняется по-разному, тем самым вскрыв не очень эффективную работу дублинской системы. Васильева привела Венгрию в качестве классического варианта того, что стали абсолютизироваться интересы не Евросоюза в целом, а интересы конкретных стран, которые раньше не выходили на передний план.

По словам Васильевой, применительно к людям, которые приезжают, имеется совершенно чёткое различие подходов, в зависимости от страны гражданства этих мигрантов. Кроме того, были введены определённые ограничения на статус этих людей, на двусторонней основе ограничивалась возможность воссоединения семей, которая раньше всегда допускалась.

В заключение Васильева отметила, что правовые аспекты, проявившиеся в ходе миграционного кризиса, представляют большое поле деятельности не только для политиков, но и для юристов. 
Раскрывая тему своего доклада «Миграция в Европу: истоки и последствия», Н.С. Ревенко условно разделил миграцию в страны ЕС на три этапа. Первый, по его мнению, относится ко второй половине XIX в. и ко всему XX в. и был связан, прежде всего, с нехваткой трудовых ресурсов в европейских странах вследствие Первой и Второй мировых войн и снижением рождаемости. Руководство европейских стран в то время было вынуждено проводить довольно либеральную иммиграционную политику, стимулировать приток иммигрантов. На тот период не было чётко структурированной политики интеграции мигрантов, да и степень адаптации у выходцев из разных стран была разной: одни предпринимали попытки к интеграции, другие продолжали замкнутую жизнь в своих анклавах. Второй этап начинается с 2004 г., после, по словам Н.С. Ревенко, не совсем продуманного ускоренного расширения Европейского союза, в результате которого больше всего пострадала Великобритания, куда переехала значительная часть населения из Польши и стран Балтии. И третий этап - это события на Ближнем и Среднем Востоке, инициатором которых стали Соединённые Штаты Америки. По мнению выступающего, американцы - великолепные тактики, но совершенно отвратительные стратеги. Они выполняют задачу тактическую, но не думают о том, что будет после этого. Пример тому - те же Афганистан, Ирак, Ливия. «Европейские же страны просто не хотят ссориться с Соединёнными Штатами, и, соответственно, испытывают все последствия, - заключил Ревенко.

В ходе дискуссий участники конференции обменялись экспертными мнениями по ряду вопросов в рамках заявленных тем. Закрыл конференцию В.Б. Белов. 